\title{
Tanaman Obat Keluarga (TOGA) dan Pemanfaatannya Sebagai Penunjang Kesehatan Masyarakat di Desa Sindangkasih
}

\author{
Sahidin $^{* 1}$, Wahyuni ${ }^{1}$, Murdjani Kamaluddin ${ }^{2}$, Suaib $^{3}$ \\ ${ }^{1}$ Fakultas Farmasi Universitas Halu Oleo, Kampus Hijau Bumi Tridharma, Jl. H. E. A. Mokodompit Kendari 93232 \\ ${ }^{2}$ Fakultas Ekonomi Universitas Halu Oleo, Kampus Hijau Bumi Tridharma, Jl. H. E. A. Mokodompit Kendari 93232 \\ ${ }^{3}$ Fakultas Pertanian Universitas Halu Oleo, Kampus Hijau Bumi Tridharma, Jl. H. E. A. Mokodompit Kendari 93232 \\ E-mail: sahidin02@uho.ac.id
}

\begin{abstract}
Abstrak
Kegiatan pengabdian pada masyarakat yang dilakukan terdiri dari program inti dan program tambahan yang bertujuan: (1) Membuat data pengelompokan tanaman yang berkhasiat sebagai obat tradisional di desa Sindangkasih (2) Memberikan edukasi kepada masyarakat mengenai cara pengolahan dan pemanfaatan dari tanaman obat keluarga, (3) Melakukan penanaman TOGA di desa Sindangkasih (4) Memberikan penyuluhan program GEMA CERMAT dan Swamedikasi (Pengobatan Mandiri) (5) Pelatihan Pembuatan Sediaan Kosmetik dan Minuman Kesehatan berbasis TOGA. Metode yang dilakukan meliputi survey lokasi penanaman, pengolahan tanah sampai siap tanam, pengadaan bibit tanaman obat, pemupukan dan pemeliharaan, serta penyuluhan tentang manfaat dan cara pengolahan tanaman obat, penyuluhan swamedikasi, Gema Cermat dan pelatihan pembuatan sediaan kosmetik dan minuman kesehatan. Hasil yang dicapai dalam kegiatan ini adalah tersedianya lahan TOGA yang dapat dimanfaatkan oleh masyarakat desa Sindangkasih, serta adanya pemahaman mengenai cara pengolahan dan pemanfaatan TOGA untuk pengobatan mandiri.
\end{abstract}

Kata kunci: TOGA, Swamedikasi, Gema Cermat, Sindangkasih, Halu Oleo

\section{Pendahuluan}

Obat tradisional di Indonesia masih digunakan secara luas di berbagai lapisan masyarakat, baik itu di desa maupun di kota. Penggunaan obat tradisional semakin meningkat dengan kecenderungan gaya hidup kembali ke alam [2]. Kecenderungan ini sangat terlihat dari maraknya produk-produk berbahan herbal yang beredar di pasaran. Disamping itu belum meratanya sarana kesehatan juga mahalnya harga obat dan banyaknya efek samping dari obat modern menjadi faktor pendorong bagi masyarakat untuk mendayagunakan obat tradisional [3]. Meskipun pengguna obat tradisional di kalangan masyarakat sudah sangat banyak namun data tentang alasan dan latar belakang masyarakat memilih menggunakan obat tradisional masih sedikit. Begitu juga data tentang jenis penyakit yang umumnya diobati dengan menggunakan obat tradisional, sehingga perlu adanya optimalisasi tanaman obat baik dari segi budidaya maupun pembuatan produk yang sesuai CPOTB [5].

Desa Sindangkasih merupakan salah satu desa di wilayah Kecamatan Ranomeeto Barat yang memiliki jumlah penduduk terbanyak berjumlah $473 \mathrm{kk}$ yang terdiri dari 1693 jiwa. Sebagian besar masyakarat bermata pencaharian sebagai petani. Sebanyak $83 \%$ masyarakatnya merupakan etnis Sunda dengan mayoritas jenjang pendidikan terakhir adalah tamatan SLTP [1]. Mayoritas masyarakat belum memahami fungsi dan penggunaan obat tradisional berdasarkan data-data ilmiah. Segi aplikasi penggunan obat tradisional di masyarakat sudah banyak yang menggunakan obat tradisional namun masih sedikit yang paham fungsi tanaman yang di gunakan sebagai obat tradisional, sehingga pengetahuan sangat berperan penting untuk mengambil sikap dan tindakan yang semestinya. Alasan masyarakat belum mengetahui fungsi dan penggunaan dari obat tradisional karena memang belum ada penyuluhan dari tenaga kesehatan khususnya tenaga kefarmasian tentang penggunaan dan manfaat dari obat tradisional. Oleh karena itu studi pengetahuan, sikap dan tindakan terhadap penggunaan obat tradisional bagi masyarakat di desa Sindangkasih perlu dilakukan.

Solusi yang ditawarkan untuk mengatasi masalah ini yakni dengan optimalisasi budidaya melalui kebun Tanaman Obat Keluarga (TOGA) dan masyarakat diikutsertakan secara aktif pada pelatihan dan pengolahan bahan baku tanaman obat menjadi bahan baku produk kesehatan sesuai dengan Cara Pembuatan Obat Tradisional yang Baik (CPOTB), serta swamedikasi obat tradisional. Selain itu, masyarakat desa juga akan diikutsertakan dalam pelatihan tentang cara pengemasan produk yang baik dan menarik, sehingga produk dapat disimpan lebih lama dan mempunyai nilai ekonomi yang lebih tinggi. Sebagai tindak lanjut kegiatan KKN PPM Tim 
pengusul akan memfasilitasi pembentukan usaha kecil yang berbasis bahan alam dan tanaman obat. Pendampingan masyarakat akan terus dilakukan dengan menjadikan Desa Sindangkasih menjadi desa binaan Universitas Halu Oleo.

\section{Metode}

Metode yang digunakan yaitu pendampingan masyarakat dalam pembuatan kebun TOGA dan pendidikan masyarakat melalui ceramah, dan praktek. Ceramah digunakan untuk memberikan pengetahuan tentang Swamedikasi penggunaan TOGA, antara lain:

a. Pendampingan dalam pembuatan TOGA, berupa pemilihan tanaman obat, penyiapan lahan, dan budidaya tanaman obat. Ada 30 macam tanaman obat yang di tanam di Kebun TOGA Desa Sindangkasih.

b. Sosialisasi kegatan kepada masyarakat Desa Sindangkasih tentang kegiatan yang akan dilaksanakan.

c. Penyuluhan untuk memberikan pengetahuan tentang Gema Cermat (Gerakan Masyarakat Cerdas Menggunakan Obat) sehingga masyarakat mengetahui cara mendapatkan obat, menggunaan obat, menyimpan obat, dan membuang obat dengan benar, serta mengajarkan pada masyarakat tentang pengobatan mandiri (Swamedikasi) dengan menggunakan TOGA.

d. Praktek: yaitu praktek pembuatan minuman kesehatan berupa minuman serbuk jahe, dan minuman jamu masuk angin, pembuatan kosmetik berupa hair tonic Aloe vera dan lulur pengantin.

Tabel 1. Tanaman koleksi Kebun TOGA Desa Sindangkasih

\begin{tabular}{|c|c|c|c|}
\hline Nama & Nama Lokal & Nama Ilmiah & Habitus \\
\hline Babadotan & Babandotan (Sunda), Bandotan (Jawa). & Ageratum conyzoides & Perdu \\
\hline Bidara & Widara (Sunda dan Jawa.) & Ziziphus mauritiana L. & Pohon \\
\hline Ciplukan & $\begin{array}{l}\text { Ciplukan (Jawa), Yoryoran (Madura), Cecendet, Cecendetan } \\
\text { (Sunda) }\end{array}$ & Physalis angulata $\mathrm{L}$. & Perdu \\
\hline Cocor Bebek & Cocor bebek (Sunda) & Kalanchoe pinnata $\mathrm{L}$. & Herba \\
\hline Daun Klorofil & Tanaman krolofil, tanaman Afrika, tanaman Afrika Selatan & Vernonia amygdalina $\mathrm{D}$. & Perdu \\
\hline Daun Salam & Ubar serai (Melayu),Salam (Sunda, Jawa dan Madura) & Syzygium polyanthum & Pohon \\
\hline Daun Sembung & $\begin{array}{l}\text { Kemandin (Madura), Sembung utan (Sunda), Siroppasparah } \\
\text { (Tapanuli Selatan) }\end{array}$ & Blumea balsamifera D. & Perdu \\
\hline Handeuleum & $\begin{array}{l}\text { Handeuleum, demung, tulak, wungu (Jawa), Daun temen- } \\
\text { temen, handeuleum (Sunda) }\end{array}$ & Graptophylum pictum $\mathrm{G}$. & Perdu \\
\hline Jahe & $\begin{array}{l}\text { Halia (Aceh), beuing (Gayo), bahing (Karo), pege (Toba), } \\
\text { sipode (Mandailing), lahia (Nias), sipodeh (Minangkabau), } \\
\text { page (Lubu), dan jahi (Lampung). }\end{array}$ & Zingiber officinale $\mathrm{L}$. & Herba \\
\hline Jambu biji & $\begin{array}{l}\text { Gglima breueh (Aceh), galiman (Batak Karo), masiambu } \\
\text { (Nias), biawas, jambu krutuk, jambu krikil, jambu biji, } \\
\text { jambu klutuk (Melayu). Jambu klutuk (Sunda). }\end{array}$ & Psidium guajava & Pohon \\
\hline Jarak pagar & $\begin{array}{l}\text { Aceh (Nawaaih), Sunda (Jarak kosta), Bugis (Peleng kaliki), } \\
\text { Madura (Kalekhe paghar), Bali (Jarak pager). }\end{array}$ & Jatropha curcas & Perdu \\
\hline Keji beling & $\begin{array}{l}\text { Daun pecah beling (Jakarta), Daun keji beling (Jawa } \\
\text { Tengah) }\end{array}$ & Strobilanthes crispus & Perdu \\
\hline Kencur & Cikur (Sunda) & Kaempferia galanga $\mathrm{L}$. & Perdu \\
\hline Kecombrang & $\begin{array}{l}\text { Wualae/ sikala (Tolaki, Sulawesi), pacikala (Bugis), honje } \\
\text { (Sunda) }\end{array}$ & Etlingera elatior & Herba \\
\hline Kumis kucing & $\begin{array}{l}\text { Remujung (Jawa), Java tea, (Inggris), giri-giri marah } \\
\text { (Sumatera), se-salasean (Madura). }\end{array}$ & Orthosiphon aristatus & Perdu \\
\hline Kunyit Putih & $\begin{array}{l}\text { Temu pao (Madura), temu mangga, temu putih (Melayu), } \\
\text { koneng joho, koneng lalap, konneng pare (Sunda). }\end{array}$ & Curcuma mangga $\mathrm{V}$. & Perdu \\
\hline Lempuyang Wangi & Lampuyang (Sunda), Lempuyang (Jawa) & Zingiber cassumunar $\mathrm{R}$. & Perdu \\
\hline Lengkuas & $\begin{array}{l}\text { Lengkueus (Gayo), Langkueueh (Aceh), Kelawas (Karo), } \\
\text { Halawas (Simalungun), Lakuwe (Nias), Lengkuas (Melayu), } \\
\text { Langkuweh (Minang), Lawas (Lampung), Laja (Sunda), } \\
\text { Laos (Jawa, Madura). }\end{array}$ & Alpinia galangal $\mathrm{L}$. & Perdu \\
\hline Mahkota dewa & simalakama (Sumatera/Melayu), makuto dewo (Jawa). & Phaleria macrocarpa & Perdu \\
\hline Manggis & Manggu (Jawa barat), manggus (Lampung). & Garcinia mangostana $\mathrm{L}$. & Pohon \\
\hline Pepaya & $\begin{array}{l}\text { Gedang (Sunda), kates (Jawa), peute, betik, ralempaya, punti } \\
\text { kayu (Sumatera). }\end{array}$ & Carica papaya $\mathrm{L}$ & Pohon \\
\hline Putri Malu & $\begin{array}{l}\text { Si meduri-duri (Sumatera), Jukut Barong (Sunda), Baret } \\
\text { (Jawa Tengah) }\end{array}$ & Mimosa pudica L. & Perdu \\
\hline Sambiloto & Andiloto(Jawa) & Andrographis paniculata & Perdu \\
\hline Serai Putih & $\begin{array}{l}\text { Sere (Jawa), sereh (Sunda), sarai (Minangkabau), sorai } \\
\text { (Lampung) }\end{array}$ & Cymbopogon citrates $\mathrm{L}$. & Perdu \\
\hline Sereh Wangi & Sere (Jawa), sereh (Sunda), & Cymbopogon nardus & Perdu \\
\hline
\end{tabular}




\section{Hasil dan Pembahasan}

\subsection{Kebun Toga}

Kegiatan pembuatan kebun TOGA, dimulai dengan penyiapan lahan seluas $40 \mathrm{~m}^{2}$. Kemudian dilakukan penggemburan tanah dan penanaman tanaman TOGA yang diperoleh dari Desa Sindangkasih, yang terdiri dari 25 jenis tanaman diantaranya: kumis kucing (Orthosiphon stamineus), temulawak (Curcuma Xanthorrhiza), Jahe (Zingiber officinale), sereh (Andropogon nordus), sambiloto (Andrographis paniculata), bidara (Ziziphus mauritiana L), daun klorofil (Vernonia amoglidina), lidah buaya (Aloe vera), keji beling (Strobhilantes crispus), kunyit putih (Curcuma mangga). Kebun TOGA ini juga dilengkapi dengan papan nama tanaman. Selain itu masyarakat diedukasi tentang pemanfaatan tanaman obat tradisonal secara empiris dan berdasarkan data ilmiah dengan memberikan penjelasan tentang mekanisme kerja bahan alam terhadap suatu penyakit [5].

\subsection{Gema Cermat dan Swamedikasi}

Kegiatan Gema Cermat dilakukan untuk meningkatkan pemahaman masyarakat tentang penggunaan obat yang baik dan benar. Mulai dari cara memperoleh obat, menggunakan obat, menyimpan obat, serta cara membuang obat dengan baik dan benar, dan mampu membedakan penggolongan obat. Swamedikasi dilakukan untuk mengajarkan bagaimana melakukan pengobatan mandiri atau pencegahan terhadap penyakit dengan menggunakan TOGA. Dalam kegiatan ini masyarakat diajarkan teknik mengolah tanaman obat, dengan cara merebus, menyeduh dan membuatnya dalam bentuk serbuk.

\subsection{Pembuatan Minuman Kesehatan}

Praktek pembuatan minuman kesehatan dilakukan dengan membuat serbuk jahe instant dan Jamu tolak angin dengan bahan dasar jahe. Jahe memiliki banyak manfaat diantaranya menjaga stamina tubuh (imunomodulator), menghangatkan tubuh, melancarkan sirkulasi darah, mengurangi nyeri haid. Jamu tolak angin terdiri dari Pada kegiatan ini juga diajarkan cara pengemasan produk yang baik, dengan menggunakan kemasan yang terstandar, sehingga dapat menjamin stabilitas dari produk yang dibuat kemasan dibuat menarik dilengkapi dengan komposisi, aturan pakai serta cara penyimpanan.

\subsection{Pembuatan Kosmetik}

Praktek pembuatan kosmetik dilakukan dengan membuat hair tonic dan lulur pengantin. Pembuatan hair tonic dilakukan dengan bahan dasar lidah buaya. Lidah buaya memiliki manfaat antara lain ; menyuburkan rambut, menghitamkan rambut, dan membuat rambut terlihat berkilau. Lulur pengantin dibuat dengan menggunakan menggunakan beras, kunyit, temulawak, daun pandan dan susu. Khasiat dari lulur ini adalah membantu pengelupasan sel mati dan mencerahkan kulit, sehingga kulit menjadi tersa halus, lembut dan bercahaya.

\section{Kesimpulan}

Hasil kegiatan pengabdian pada masyarakat terintegrasi KKN tematik di desa Sindangkasih berupa adanya peningkatan pemahaman masyarakat tentang pemanfaatan tanaman obat keluarga yang direalisasikan dengan pembuatan lahan TOGA. Pengetahuan mengenai TOGA ini menjadi dasar untuk melakukan pengobatan swamedikasi dan pembuatan berbagai macam produk berbahan dasar TOGA.

\section{Ucapan Terima Kasih}

Ucapan terima kasih kami sampaikan kepada Rektor Universitas Halu Oleo atas pendanaan pengabdian kepada masyarakat terintegrasi KKN Tematik melalui Dana Internal BLU UHO 2018.

\section{Daftar Pustaka}

1. BPS Konawe Selatan, 2017, Kecamatan Ranomeeto Barat Dalam Angka, Badan Pusat Statistik Kabupaten Konawe Selatan, Katalog BPS: 1102001.7405091, Nomor Publikasi:74050.1724, ISSN/ISBN:978-6026422-24-8, Tanggal Rilis : 2017-09-20

2. Pramono S, Tingkat Manfaat dan Keamanan Tanaman Obat Tradisional, Yogyakarta: Fakultas Farmasi Universitas Gajah Mada, 2008.

3. Pramono S, Kontribusi bahan obat alam dalam mengatasi krisis bahan obat di Indonesia. Jurnal Bahan Alam Indonesia, 2002, 1(1); 18-20.

4. Untung O. Herbal Indonesia Berkhasiat (Bukti Ilmiah \& Cara Racik), Volume 08. Bogor: PT. Trubus Swadaya.

5. Widyawaruyanti A., Zaini NC, Syafruddin, 2011, Mekanisme dan Aktivitas Antimalaria dari Senyawa Flavonoid yang Diisolasi dari Cempedak (Artocarpus champeden), Jurnal Bina Praja, Vol. 13(2) 